\title{
Effect of Cultivar and Different Plant Spacing on Growth and Yield of Cauliflower under Southern Agro-climatic Zone of Andhra Pradesh
}

\author{
Ramesha Moratagi ${ }^{1}$, P. Syam Sundar Reddy ${ }^{1 *}$, Syed Sadarunnisa ${ }^{1}$, \\ V. V. Padmaja ${ }^{2}$ and A. Ramanjaneya Reddy ${ }^{3}$ \\ ${ }^{1}$ Department of Vegetable Science, ${ }^{2}$ Department of Plant Physiology, College of Horticulture, \\ Anantharajupeta, Andhra Pradesh, India \\ ${ }^{3}$ Dept. of Soil Science, HRS, Bayapagaripalli, Madanapalli, Chittoor Dist., India
}

*Corresponding author

\section{A B S T R A C T}

Keywords

Cauliflower, Spacing, Growth, Curd diameter, Curd weight and yield

Article Info

Accepted:

18 December 2020

Available Online:

10 January 2021
A field experiment was conducted to study the suitability of cauliflower (Brassica oleracea var. botrytis L.) cultivars with different plant densities for southern Agro climatic zone of Andhra Pradesh". The experiment was conducted with four cultivars and three spicing levels. The treatments were replicated thrice in two factorial randomized block design. Highly significant differences were observed for growth and yield parameters. Among the cultivars Pusa Meghana $\left(V_{2}\right)$ was found to be superior for all growth parameters under study viz., plant height, stalk length, number of leaves per plant, petiole length, leaf area, leaf area index and total dry matter content. Among the spacing levels $\mathrm{S}_{3}$ $(60 \mathrm{~cm} \times 45 \mathrm{~cm})$ recorded highest in all growth parameters while, among the interaction effects Pusa Meghana with $\mathrm{S}_{3}(60 \mathrm{~cm} \times 45 \mathrm{~cm})$ spacing levels $\left(\mathrm{V}_{2} \mathrm{~S}_{3}\right)$ recorded highest in all growth parameters. Regarding yield parameters Pusa Meghana recorded maximum curd weight, curd diameter, curd size index and yield per hectare. Whereas, spacing level $45 \mathrm{~cm}$ x $45 \mathrm{~cm}\left(\mathrm{~S}_{2}\right)$ recorded highest under all yield parameters. Among the interaction effects the cultivar Pusa Meghana with $45 \mathrm{~cm}$ x $45 \mathrm{~cm}$ spacing levels $\left(\mathrm{V}_{2} \mathrm{~S}_{2}\right)$ recorded highest in all yield parameters.

\section{Introduction}

Cauliflower (Brassica oleracea var. botrytis L.) is one of the most important cruciferous vegetables grown in India and has originated from the Mediterranean region. Cauliflower $(2 n=18)$ belongs to the family Brassicaceae. It is grown for its white tender curd and contains substantial amount of protein, carbohydrates, phosphorous, calcium, iron and ascorbic acid. Its curds are used as cooked vegetable either singly or mixed with other (Choube et al., 2020). It is rich in minerals, carbohydrates and vitamins $\mathrm{A}$ and C. It is a delicate crop and can be damaged by freezing weather near harvesting. The plants may fail to form desirable heads in dry and hot weather which cause the heads to develop prematurely and bolt or button. It requires moderately cool climates during the periods 
of its growth. Crop production is a complex phenomenon and is the outcome of several inter-ranked factors. Agronomic research in general aims at improving cultural practices of crop varieties to rely optimum yield. In recent years, there has been a growing interest in the use of narrow rows as well as narrow plant spacing for the production of cauliflower because of higher labour energy and equipment's required for the cultivation.

\section{Materials and Methods}

A field experiment was conducted at Vegetables block, College of Horticulture, Anantharajupeta, Dr. Y. S. R. Horticultural University, Andhra Pradesh during rabi 2019. The experiment consists of four cultivar levels viz $\mathrm{V}_{1}$ : Pusa Sharad, $\mathrm{V}_{1}$ : Pusa Meghana, $\mathrm{V}_{1}$ : Pusa Karthiki and $\mathrm{V}_{4}$ : Pusa Ashwini and three spacing levels viz., $\mathrm{S}_{1}: 45$ $\mathrm{cm} \times 30 \mathrm{~cm}, \mathrm{~S}_{2}: 45 \mathrm{~cm}$ x $45 \mathrm{~cm}\left(5\right.$ plants $\left.\mathrm{m}^{-2}\right)$ and $\mathrm{S}_{3}: 60 \mathrm{~cm} \mathrm{x} 45 \mathrm{~cm}$ (4 plants $\mathrm{m}^{-2}$ ). The experiment was conducted in a factorial randomized block design (FRBD) with three replications. The data on growth parameters viz. plant height, stalk length, number of leaves per plant, petiole length, leaf area, leaf area index and total dry matter content and yield parameters viz., curd weight, curd diameter, curd size index and yield per hectare were recorded and the data was statistically analyzed using analysis of variance following the method of Panse and Sukhatme (1978) and the mean values were compared at $5 \%$ level of significance.

\section{Results and Discussion}

\section{Effect of cultivar and spacing levels on growth parameters of cauliflower}

The results pertaining to influence of cultivars, spacing levels and combined effect of cultivars and spacing levels on growth parametrs is presented in Table 1 and 2 .
Results indicated significant differences among the cultivars, spacing levels and interaction effects pertaining to growth parameters.

\section{Plant height (cm)}

Pusa Meghana (64.62) and $60 \mathrm{~cm} \mathrm{x} 45 \mathrm{~cm}$ (59.20) had showed significantly highest plant height among the cultivars and different plant spacings respectively at harvest. Among the interactions Pusa Meghana with 60 x $45 \mathrm{~cm}$ spacing $\left(\mathrm{V}_{2} \mathrm{~S}_{3}\right)$ recorded highest plant height (68.89) followed by $\mathrm{V}_{2} \mathrm{~S}_{2}$ (68.47). Lowest plant height (36.26) was recorded in Pusa Ashwini with $45 \times 30 \mathrm{~cm}$ spacing $\left(\mathrm{V}_{4} \mathrm{~S}_{1}\right)$. The increased plant height of cauliflower during this study due to wider plant spacing might be due to lesser competition for nutrients, moisture, and $\mathrm{CO}_{2}$ among the roots of the plants. In contrary to this, closer spacing created more competition for the resources in the roots of plants and resulted in lower plant height. This might be due to more terminal increase in closer spaced plants than wider spaced plants, where lateral growth is more. These findings agreed with Joshi et al., (2018), Gurjeet et al., (2016) in broccoli, Saikia et al., (2010), Sani et al., (2018), Kannan et al., (2016), and Khatiwada (2000) also reported the taller height of cabbage under greater spacing.

\section{Stalk length (cm)}

Pusa Meghana (15.49) and $60 \mathrm{~cm} \mathrm{x} 45 \mathrm{~cm}$ (13.36) had showed significantly highest stalk length among the cultivars and different plant spacings respectively at harvest. Combined effect of Pusa Meghana with $60 \times 45 \mathrm{~cm}$ spacing $\left(\mathrm{V}_{2} \mathrm{~S}_{3}\right)$ recorded highest stalk length (15.96) followed by $\mathrm{V}_{2} \mathrm{~S}_{2} \quad$ (15.27). Pusa Karthiki with $45 \times 45 \mathrm{~cm}$ spacing $\left(\mathrm{V}_{3} \mathrm{~S}_{2}\right)$ was recorded by lowest stalk length (11.30). The observed differences in stalk length of cultivars are mainly due to the genotype of 
each cultivar. Similar findings have been also found by Srivastava et al., (2011) and Gabhale et al., (2014) in cauliflower, Giri et al., (2013) and Zaki et al., (2015) in broccoli.

\section{Number of leaves per plant}

Pusa Meghana (24.41) and $45 \mathrm{~cm} \mathrm{x} 45 \mathrm{~cm}$ (23.31) had showed significantly highest number of leaves among the cultivars and different plant spacings respectively at harvest. Among the interactions Pusa Meghana with $60 \times 45 \mathrm{~cm}$ spacing $\left(\mathrm{V}_{2} \mathrm{~S}_{3}\right)$ recorded highest number of leaves (25.89) followed by $\mathrm{V}_{2} \mathrm{~S}_{2}$ (25.68). Pusa Sharad with $60 \times 45 \mathrm{~cm}$ spacing $\left(\mathrm{V}_{1} \mathrm{~S}_{3}\right)$ has recorded lowest number of leaves (21.51). Number of leaves per plant was increased with plant spacing and decreased with closer spacing. This might be due to lesser competition for nutrients and light amongst the plants with wider plant spacing. Hence, in wider spacing due to the availability of more space and light, the crop might have produced a greater number of leaves per plant. The higher numbers of leaves in $60 \times 45 \mathrm{~cm}$ spacing might be due to more availability of resources for the growth and development of the leaves. The more space also provides the better exposure of plants tor photosynthesis. These results were in conformity with the results of Archana et al., (2019), Bacha et al., (2017), Arora et al., (2002), Durate and Fortuno (2005) in Chinese cabbage, Joshi et al., (2018), Gabhale et al., (2014), Yadav et al., (2013), Srivastava et al., (2011) in cauliflower and Agarakar et al., (2010), Giri et al., (2013) and Zaki et al., (2015) in broccoli. Arin et al., (2003) and EI-Bassiony et al., (2014) in kohlrabi.

\section{Petiole length $(\mathrm{cm})$}

Pusa Meghana (11.53) and $60 \mathrm{~cm} \mathrm{x} 45 \mathrm{~cm}$ (11.07) had showed significantly highest petiole length among the cultivars and different plant spacings respectively at harvest. Combined effect of Pusa Meghana with $60 \times 45 \mathrm{~cm}$ spacing $\left(\mathrm{V}_{2} \mathrm{~S}_{3}\right)$ recorded highest petiole length (12.88) followed by $\mathrm{V}_{4} \mathrm{~S}_{1}$ (12.59). Pusa Sharad with $60 \mathrm{~cm} \times 45$ cm spacing $\left(\mathrm{V}_{1} \mathrm{~S}_{3}\right)$ has recorded lowest petiole length (9.36). This might be due to lesser competition for nutrients and light amongst the plants with wider plant spacing. The more space also provides the better exposure of plants to photosynthesis. Similar results have been found by Srivastava et al., (2011) in cauliflower and Chaudhari et al., (2015) in knol-khol.

\section{Leaf area $\left(\mathrm{cm}^{2}\right)$}

Pusa Meghana (827.43) and $60 \mathrm{~cm} \mathrm{x} 45 \mathrm{~cm}$ (773.32) had showed significantly highest leaf area among the cultivars and different plant spacings respectively at harvest. Among the interactions Pusa Meghana with 60 x $45 \mathrm{~cm}$ spacing $\left(\mathrm{V}_{2} \mathrm{~S}_{3}\right)$ recorded highest leaf area (845.33) followed by $\mathrm{V}_{2} \mathrm{~S}_{2}$ (843.71). Pusa Ashwini with $45 \times 30 \mathrm{~cm}$ spacing $\left(\mathrm{V}_{4} \mathrm{~S}_{1}\right)$ has recorded lowest leaf area (684.98). During the different stages of crop growth, wider spacing $\left(\mathrm{S}_{3}\right)$ gave significantly superior leaf area over other levels of spacing.

These results might be attributed to optimum use of natural resources by reducing the competition for uptake of nutrients in widely spacing plants compared to the narrow spacing ones.

The above results were in accordance with Criollo and Garcia (2009) in radish and Agarkar et al., (2010) in broccoli. At harvest, the maximum leaf area was observed in Pusa Sharad and Pusa Meghana at $S_{1}$ and $S_{2}$ respectively. While, the minimum leaf area was observed in Pusa Ashwini at $\mathrm{S}_{3}$. The plant spread was increased as the plant spacing increases. 
Table.1 Effect of different cultivars and plant spacing on plant height, Stalk length, Number of leaves per plant and petiole length of cauliflower

\begin{tabular}{|c|c|c|c|c|c|c|c|c|c|c|c|c|c|c|c|c|}
\hline \multirow{2}{*}{$\begin{array}{l}\text { Spacing } \\
\text { Cultivar }\end{array}$} & \multicolumn{4}{|c|}{ Plant height (cm) } & \multicolumn{4}{|c|}{ Stalk length (cm) } & \multicolumn{4}{|c|}{ Number of leaves per plant } & \multicolumn{4}{|c|}{ Petiole length(cm) } \\
\hline & $\mathbf{S}_{1}$ & $\mathbf{S}_{\mathbf{2}}$ & $\mathbf{S}_{\mathbf{3}}$ & Mean & $\mathbf{S}_{1}$ & $\mathbf{S}_{2}$ & $\mathbf{S}_{3}$ & Mean & $\mathbf{S}_{1}$ & $\mathbf{S}_{2}$ & $\mathbf{S}_{3}$ & Mean & $\mathbf{S}_{\mathbf{1}}$ & $\mathbf{S}_{2}$ & $\mathbf{S}_{3}$ & Mean \\
\hline $\mathbf{V}_{1}$ & 68.29 & 62.58 & 49.51 & 60.12 & 12.36 & 13.06 & 13.48 & 12.96 & 22.66 & 23.51 & 21.51 & 22.56 & 10.10 & 11.74 & 9.36 & 10.40 \\
\hline $\mathbf{V}_{2}$ & 56.52 & 68.47 & 68.89 & 64.62 & 15.23 & 15.27 & 15.96 & 15.49 & 21.67 & 25.68 & 25.89 & 24.41 & 9.54 & 12.17 & 12.88 & 11.53 \\
\hline $\mathbf{V}_{3}$ & 62.61 & 49.13 & 56.24 & 55.99 & 13.37 & 11.30 & 12.64 & 12.44 & 23.37 & 21.58 & 22.29 & 22.41 & 11.43 & 9.51 & 10.73 & 10.56 \\
\hline $\mathbf{V}_{4}$ & 36.26 & 38.85 & 62.39 & 45.83 & 11.31 & 12.68 & 11.38 & 11.79 & 25.18 & 22.47 & 23.50 & 23.71 & 12.59 & 10.11 & 11.32 & 11.34 \\
\hline Mean & 55.92 & 54.76 & 59.20 & & 13.07 & 13.08 & 13.36 & & 23.22 & 23.31 & 23.30 & & 10.92 & 10.88 & 11.07 & \\
\hline \multicolumn{17}{|c|}{ Interaction effect } \\
\hline Source & V & $\mathbf{S}$ & VX S & & V & $\mathbf{S}$ & VXS & & V & $\mathbf{S}$ & VX S & & V & $\mathbf{S}$ & VXS & \\
\hline S.Em \pm & 0.18 & 0.12 & 0.02 & & 0.17 & 0.08 & 0.02 & & 0.17 & 0.08 & 0.01 & & 0.08 & 0.05 & 0.01 & \\
\hline $\begin{array}{c}\text { CD at } \\
5 \%\end{array}$ & 0.69 & 0.34 & 0.24 & & 0.68 & 0.25 & 0.17 & & 0.67 & 0.31 & 0.20 & & 0.33 & 0.14 & 0.05 & \\
\hline
\end{tabular}

$\mathrm{V}_{1}=$ Pusa Sharad, $\mathrm{V}_{2}=$ Pusa Meghana, $\mathrm{V}_{3}=$ Pusa Karthiki, $\mathrm{V}_{4}=$ Pusa Ashwini

$\mathrm{S}_{1}=45 \mathrm{~cm} \times 30 \mathrm{~cm}, \mathrm{~S}_{2}=45 \mathrm{~cm} \times 45 \mathrm{~cm}, \mathrm{~S}_{3}=60 \mathrm{~cm} \times 45 \mathrm{~cm}$

Table.2 Effect of different cultivars and plant spacing on Leaf area, Leaf Area Index and Total dry matter per plant of cauliflower

\begin{tabular}{|c|c|c|c|c|c|c|c|c|c|c|c|c|}
\hline \multirow{2}{*}{$\begin{array}{l}\text { Spacing } \\
\text { Cultivar }\end{array}$} & \multicolumn{4}{|c|}{ Leaf area $\left(\mathrm{cm}^{2}\right)$} & \multicolumn{4}{|c|}{ Leaf Area Index (\%) } & \multicolumn{4}{|c|}{ Total dry matter per plant(g) } \\
\hline & $\mathbf{S}_{1}$ & $\mathbf{S}_{2}$ & $\mathbf{S}_{\mathbf{3}}$ & Mean & $\mathbf{S}_{1}$ & $\mathbf{S}_{2}$ & $\mathbf{S}_{\mathbf{3}}$ & Mean & $\mathbf{S}_{1}$ & $\mathbf{S}_{2}$ & $\mathbf{S}_{3}$ & Mean \\
\hline $\mathbf{V}_{1}$ & 765.05 & 794.59 & 685.85 & 748.49 & 13.49 & 18.89 & 11.47 & 14.62 & 140.22 & 155.48 & 155.76 & 150.49 \\
\hline $\mathbf{V}_{2}$ & 793.24 & 843.71 & 845.33 & 827.43 & 18.25 & 17.73 & 17.61 & 17.87 & 165.45 & 165.41 & 165.85 & 165.57 \\
\hline $\mathbf{V}_{3}$ & 793.11 & 685.11 & 765.62 & 747.94 & 17.51 & 11.39 & 13.24 & 14.05 & 155.54 & 125.40 & 140.62 & 140.52 \\
\hline $\mathbf{V}_{4}$ & 684.98 & 764.41 & 848.59 & 765.99 & 11.56 & 13.91 & 18.75 & 14.74 & 125.26 & 140.31 & 125.78 & 130.45 \\
\hline Mean & 772.12 & 771.96 & 773.32 & & 15.20 & 15.48 & 15.27 & & 146.61 & 146.65 & 147.00 & \\
\hline \multicolumn{13}{|c|}{ Interaction effect } \\
\hline Source & $\mathbf{V}$ & $\mathbf{S}$ & $\mathbf{V} \times \mathbf{S}$ & & $\mathbf{V}$ & $\mathbf{S}$ & $\mathbf{V} \times \mathbf{S}$ & & $\mathbf{V}$ & $\mathbf{S}$ & $\mathbf{V} \times \mathbf{S}$ & \\
\hline S.Em \pm & 1.43 & 0.79 & 1.13 & & 0.13 & 0.08 & 0.01 & & 0.15 & 0.07 & 0.01 & \\
\hline CD at $5 \%$ & 5.61 & 2.55 & 14.30 & & 0.53 & 0.22 & 0.12 & & 0.57 & 0.20 & 0.11 & \\
\hline
\end{tabular}

$\mathrm{V}_{1}=$ Pusa Sharad, $\mathrm{V}_{2}=$ Pusa Meghana, $\mathrm{V}_{3}=$ Pusa Karthiki, $\mathrm{V}_{4}=$ Pusa Ashwini

$\mathrm{S}_{1}=45 \mathrm{~cm} \times 30 \mathrm{~cm}, \mathrm{~S}_{2}=45 \mathrm{~cm} \times 45 \mathrm{~cm}, \mathrm{~S}_{3}=60 \mathrm{~cm} \times 45 \mathrm{~cm}$ 
Table.3 Effect of different cultivars and plant spacing on curd weight, curd diameter, curd size index and yield per hectare of cauliflower at different growth intervals

\begin{tabular}{|c|c|c|c|c|c|c|c|c|c|c|c|c|c|c|c|c|}
\hline \multirow{2}{*}{$\begin{array}{c}\text { Spacin } \\
\mathbf{g} \\
\text { Cultiva } \\
\mathbf{r}\end{array}$} & \multicolumn{4}{|c|}{ Curd weight (g) } & \multicolumn{4}{|c|}{ Curd diameter (cm) } & \multicolumn{4}{|c|}{ Curd size index $\left(\mathrm{cm}^{3}\right)$} & \multicolumn{4}{|c|}{ Yield per hectare (tons) } \\
\hline & $\mathbf{S}_{1}$ & $\mathbf{S}_{2}$ & $\mathrm{~S}_{3}$ & Mean & $\mathbf{S}_{1}$ & $\mathbf{S}_{2}$ & $\mathbf{S}_{3}$ & $\begin{array}{c}\text { Mea } \\
\text { n }\end{array}$ & $S_{1}$ & $\mathbf{S}_{2}$ & $\mathbf{S}_{3}$ & Mean & $S_{1}$ & $\mathbf{S}_{2}$ & $\mathbf{S}_{3}$ & $\begin{array}{c}\text { Mea } \\
\mathbf{n}\end{array}$ \\
\hline$V_{1}$ & $\begin{array}{c}605.5 \\
3 \\
\end{array}$ & $\begin{array}{c}789.5 \\
2 \\
\end{array}$ & $\begin{array}{c}511.2 \\
0\end{array}$ & $\begin{array}{c}635.4 \\
2 \\
\end{array}$ & $\begin{array}{c}17.5 \\
0 \\
\end{array}$ & $\begin{array}{c}19.5 \\
7 \\
\end{array}$ & $\begin{array}{c}18.4 \\
0\end{array}$ & 18.49 & $\begin{array}{c}170.6 \\
6\end{array}$ & $\begin{array}{c}180.5 \\
0 \\
\end{array}$ & $\begin{array}{c}185.3 \\
3 \\
\end{array}$ & $\begin{array}{c}178.8 \\
3 \\
\end{array}$ & $\begin{array}{c}27.5 \\
0 \\
\end{array}$ & $\begin{array}{c}29.3 \\
1 \\
\end{array}$ & $\begin{array}{c}25.5 \\
3 \\
\end{array}$ & 27.44 \\
\hline $\mathbf{V}_{2}$ & $\begin{array}{c}876.8 \\
5\end{array}$ & $\begin{array}{c}827.1 \\
1\end{array}$ & $\begin{array}{c}885.9 \\
2\end{array}$ & $\begin{array}{c}863.2 \\
9\end{array}$ & $\begin{array}{c}16.3 \\
9\end{array}$ & $\begin{array}{c}18.3 \\
6\end{array}$ & $\begin{array}{c}19.9 \\
3\end{array}$ & 18.22 & $\begin{array}{c}220.3 \\
3\end{array}$ & $\begin{array}{c}220.3 \\
3\end{array}$ & $\begin{array}{c}220.8 \\
3\end{array}$ & $\begin{array}{c}220.5 \\
0\end{array}$ & $\begin{array}{c}29.6 \\
0\end{array}$ & $\begin{array}{c}33.8 \\
7\end{array}$ & $\begin{array}{c}33.4 \\
5\end{array}$ & 32.30 \\
\hline $\mathbf{V}_{3}$ & $\begin{array}{c}750.4 \\
9\end{array}$ & $\begin{array}{c}555.9 \\
7\end{array}$ & $\begin{array}{c}682.2 \\
8\end{array}$ & $\begin{array}{c}662.9 \\
1 \\
\end{array}$ & $\begin{array}{c}18.7 \\
1\end{array}$ & $\begin{array}{c}16.3 \\
2\end{array}$ & $\begin{array}{c}17.3 \\
5\end{array}$ & 17.46 & $\begin{array}{c}180.9 \\
3\end{array}$ & $\begin{array}{c}150.1 \\
7\end{array}$ & $\begin{array}{c}170.5 \\
0\end{array}$ & $\begin{array}{c}167.2 \\
0\end{array}$ & $\begin{array}{c}25.5 \\
1\end{array}$ & $\begin{array}{c}25.6 \\
1\end{array}$ & $\begin{array}{c}27.8 \\
7 \\
\end{array}$ & 26.33 \\
\hline $\mathbf{V}_{4}$ & $\begin{array}{c}507.4 \\
3\end{array}$ & $\begin{array}{c}631.1 \\
7\end{array}$ & $\begin{array}{c}751.3 \\
3\end{array}$ & $\begin{array}{c}629.9 \\
7\end{array}$ & $\begin{array}{c}19.6 \\
2\end{array}$ & $\begin{array}{c}17.5 \\
4\end{array}$ & $\begin{array}{c}16.4 \\
4\end{array}$ & 17.86 & $\begin{array}{c}150.4 \\
4\end{array}$ & $\begin{array}{c}170.5 \\
0\end{array}$ & $\begin{array}{c}150.5 \\
0\end{array}$ & $\begin{array}{c}157.1 \\
5\end{array}$ & $\begin{array}{c}27.5 \\
7\end{array}$ & $\begin{array}{c}33.6 \\
0\end{array}$ & $\begin{array}{c}29.7 \\
0\end{array}$ & 30.29 \\
\hline Mean & $\begin{array}{c}685.0 \\
7\end{array}$ & $\begin{array}{c}700.9 \\
4\end{array}$ & $\begin{array}{c}707.6 \\
8\end{array}$ & & $\begin{array}{c}18.0 \\
6\end{array}$ & $\begin{array}{c}17.9 \\
5\end{array}$ & $\begin{array}{c}18.0 \\
3\end{array}$ & & $\begin{array}{c}180.5 \\
9\end{array}$ & $\begin{array}{c}180.3 \\
7\end{array}$ & $\begin{array}{c}181.7 \\
9\end{array}$ & & $\begin{array}{c}27.5 \\
4\end{array}$ & $\begin{array}{c}30.5 \\
9\end{array}$ & $\begin{array}{c}29.1 \\
3\end{array}$ & \\
\hline Interact & $n$ effect & & & & & & & & & & & & & & & \\
\hline Source & $\mathbf{V}$ & $\mathbf{S}$ & $\mathbf{V} \times \mathbf{S}$ & & V & $\mathbf{S}$ & $\begin{array}{l}\mathbf{V} \times \\
S\end{array}$ & & V & $\mathbf{S}$ & $\mathbf{V} \times \mathbf{S}$ & & V & $\mathbf{S}$ & $\begin{array}{c}\mathbf{V} \times \\
S\end{array}$ & \\
\hline S.Em \pm & 7.92 & 4.50 & 35.62 & & 0.17 & 0.08 & 0.01 & & 0.14 & 0.08 & 0.01 & & 0.16 & 0.08 & 0.01 & \\
\hline $\begin{array}{c}\text { CD at } \\
5 \%\end{array}$ & 31.08 & 13.20 & $\begin{array}{c}410.1 \\
8\end{array}$ & & 0.67 & 0.30 & 0.20 & & 0.55 & 0.23 & 0.13 & & 0.63 & 0.29 & 0.18 & \\
\hline
\end{tabular}

$\mathrm{V}_{1}=$ Pusa Sharad, $\mathrm{V}_{2}=$ Pusa Meghana, $\mathrm{V}_{3}=$ Pusa Karthiki, $\mathrm{V}_{4}=$ Pusa Ashwini

$\mathrm{S}_{1}=45 \mathrm{~cm} \times 30 \mathrm{~cm}, \mathrm{~S}_{2}=45 \mathrm{~cm} \times 45 \mathrm{~cm}, \mathrm{~S}_{3}=60 \mathrm{~cm} \times 45 \mathrm{~cm}$

Significantly, superior plant spread was attained in cauliflower at all the stages of growth with higher plant spacing $(60 \mathrm{~cm} \times 45$ $\mathrm{cm}$ ), which could be attributed to the fact that in wider spacing, the individual plant gets plenty of light and more nutrients in comparison to narrow spacing. Wider plant spacing leads to good growth and development, less competition for the uptake of nutrients, water and sunlight, which leads to more lateral growth and spread. The results of present findings agreed with the findings of Munro et al., (2007), Bhangre et al., (2010) and Tejaswini et al., (2018) in broccoli, Saikia et al., (2010), Ali et al., (2018) in turnip and Sharma and Chaudhary (1996) in cauliflower.

\section{Leaf area index (LAI)}

Pusa Meghana (17.87) and $45 \mathrm{~cm} \mathrm{x} 45 \mathrm{~cm}$ (15.48) had showed significantly highest LAI among the cultivars and different plant spacings respectively at harvest. Combined effect of Pusa Sharad with $45 \mathrm{~cm} \mathrm{x} 45 \mathrm{~cm}$ spacing $\left(\mathrm{V}_{1} \mathrm{~S}_{2}\right)$ has recorded highest LAI
(18.89) followed by $\mathrm{V}_{4} \mathrm{~S}_{3}$ (18.75). Pusa Karthiki with $45 \mathrm{~cm} \times 45 \mathrm{~cm}$ spacing $\left(\mathrm{V}_{3} \mathrm{~S}_{2}\right)$ has recorded lowest LAI (11.39). The leaf area index (LAI) is mainly noticed the photosynthetic area of any plant. The results of present findings agreed with the findings of Dipak (2019) in cauliflower.

\section{Dry matter per plant (g)}

Pusa Meghana (165.57) and $60 \mathrm{~cm} \mathrm{x} 45 \mathrm{~cm}$ (147.00) had showed significantly highest dry matter among the cultivars and different plant spacings respectively at harvest. Among the interactions Pusa Meghana with $45 \mathrm{~cm}$ x 30 $\mathrm{cm}$ spacing $\left(\mathrm{V}_{2} \mathrm{~S}_{1}\right)$ recorded highest dry matter (165.45) followed by $\mathrm{V}_{2} \mathrm{~S}_{2}$ (165.41). Pusa Ashwini with $45 \mathrm{~cm} \times 30 \mathrm{~cm}$ spacing $\left(\mathrm{V}_{4} \mathrm{~S}_{1}\right)$ has recorded lowest dry matter (125.26). The increased stomatal conductance may help in increased gaseous exchange thereby increased rate of photosynthesis, higher crop growth rate per unit area in coordination with increased dry matter production. These results were in conformity with the findings of Tejaswini et al., (2018) in 
cauliflower, Chandan et al., (2013), Uddain et al., (2012) in Knol-khol, Kalloo et al., (2005) in vegetable pea. Bhangre et al., (2011) in cabbage. The highest dry matter content might be due to its higher plant height, a greater number of leaves and leaf area. These findings are in accordance with Thakur et al., (1991) and Sani et al., (2018) in cabbage.

\section{Effect of cultivar and spacing levels on yield parameters of cauliflower}

The results pertaining to influence of cultivars, spacing levels and combined effect of cultivars and spacing levels on yield parameters is presented in Table 3. Results indicated significant differences among the cultivars, spacing levels and interaction effects pertaining to yield parameters.

\section{Curd weight (g)}

Among the cultivars significantly highest curd weight (863.29) was recorded in Pusa Meghana while among the different plant spacings maximum curd weight (707.68) was recorded with $\mathrm{S}_{3}(60 \mathrm{~cm} \times 45 \mathrm{~cm})$. Combined effect of Pusa Meghana under $60 \mathrm{~cm} \mathrm{x} 45 \mathrm{~cm}$ spacing $\left(\mathrm{V}_{2} \mathrm{~S}_{3}\right)$ recorded highest curd weight (885.92) followed by $\mathrm{V}_{2} \mathrm{~S}_{1}$ (876.85). Lowest curd weight (507.43) was recorded in Pusa Ashwini with $45 \mathrm{~cm} \times 30 \mathrm{~cm}\left(\mathrm{~V}_{4} \mathrm{~S}_{1}\right)$. Higher curd weight under wider spacing might be due to higher dry matter production and lesser competition for nutrients, space and moisture resulting in proper utilization of accumulates which were conserved by the plant, under optimally.

These results are in line with the previous findings of Oad et al., (2002) who recommended $45 \mathrm{~cm}$ plant spacing as the most successful plant spacing for getting the higher yield of cauliflower, whereas the narrow plant spacing could not record satisfactory plant characteristics. Similar results were reported by Srivastava et al., (2011) and Gabhale et al., (2014) in cauliflower, Arin et al., (2003) and EIBassiony et al., (2014) in knol-khol.

\section{Curd diameter (cm)}

Pusa Meghana (19.10) and $60 \mathrm{~cm} \mathrm{x} 45 \mathrm{~cm}$ (19.28) had showed significantly highest curd diameter among the cultivars and different plant spacings respectively. Among the interactions Pusa Meghana with $60 \mathrm{~cm}$ x 45 $\mathrm{cm}$ spacing $\left(\mathrm{V}_{2} \mathrm{~S}_{3}\right)$ recorded highest curd diameter (19.93) followed by $\mathrm{V}_{2} \mathrm{~S}_{2}$ and $\mathrm{V}_{4} \mathrm{~S}_{3}$ (19.26 and 19.25). Pusa Ashwini with $45 \mathrm{~cm}$ x $30 \mathrm{~cm}$ spacing $\left(\mathrm{V}_{4} \mathrm{~S}_{1}\right)$ has recorded lowest curd diameter (17.62).

The closer plant spacing showed poor results due to close competition for acquiring the nutrients, sunlight, and space for better curd growth and development. The lower plant density or wider spacing provides more space where the individual plant enjoyed a maximum suitable environment which resulted for the development of curd with maximum diameter. Similar result was given by Archana et al., (2019), Joshi et al., (2018), Bacha et al., (2017) in cauliflower.

\section{Curd size index $\left(\mathrm{cm}^{3}\right)$}

Among the cultivars significantly highest CSI (220.53) was recorded in Pusa Meghana while among the different plant spacings maximum CSI (181.79) was recorded in $\mathrm{S}_{3}(60 \mathrm{~cm} \times 45$ $\mathrm{cm})$. Combined effect of Pusa Meghana with $60 \mathrm{~cm} \times 45 \mathrm{~cm}$ spacing $\left(\mathrm{V}_{2} \mathrm{~S}_{3}\right)$ recorded highest CSI (220.83) followed by $\mathrm{V}_{2} \mathrm{~S}_{1}, \mathrm{~V}_{2} \mathrm{~S}_{2}$ (220.33). Lowest CSI (150.17) was recorded in Pusa Karthiki with $45 \mathrm{~cm}$ x $45 \mathrm{~cm}$ spacing $\left(V_{3} S_{2}\right)$. curd size index in cauliflower was increased with increase in the spacing levels. These findings agreed with those of Gazala et al., (2017) in cauliflower. 


\section{Yield per hectare (tons)}

Among the cultivars, Pusa Meghana followed by Pusa Ashwini recorded significantly highest curd yield (32.30 and 30.29), while among the different spacing levels, $45 \mathrm{~cm} \mathrm{x}$ $45 \mathrm{~cm}\left(\mathrm{~S}_{2}\right)$ (30.59) followed by $\left(\mathrm{S}_{3}\right) 60 \mathrm{~cm} \mathrm{x}$ $45 \mathrm{~cm}$ (29.13) showed significantly highest curd yield per hectare. Among the interactions Pusa Meghana with $45 \mathrm{~cm} \times 45 \mathrm{~cm}$ spacing $\left(\mathrm{V}_{2} \mathrm{~S}_{2}\right)$ followed by Pusa Ashwini with $45 \mathrm{~cm}$ $\mathrm{x} 45 \mathrm{~cm}$ spacing $\left(\mathrm{V}_{4} \mathrm{~S}_{2}\right)$ recorded highest curd yield (33.87 and 33.60). Pusa Karthiki with $45 \mathrm{~cm} \times 30 \mathrm{~cm}$ spacing $\left(\mathrm{V}_{3} \mathrm{~S}_{1}\right)$ has recorded lowest yield (25.51). The significantly maximum curd yield per hectare was obtained with moderate spacing $\left(S_{2}\right)$ followed by wider spacing $\left(S_{3}\right)$ compared to closer spacing $\left(S_{1}\right)$. The cauliflower yield increased with an increase in plant spacing up to an absolute limit, and after $45 \mathrm{~cm}$ spacing, it started decreasing. Low yield in case of close spacing might be due to the higher mortality rate, lower plant height and lesser numbers of leaves per plant, shorter diameter of curd and also the competitive growth of the plants. The main reason for maximum curd yield per ha in medium plant spacing was due to higher plant population per unit area compared to wider spacing. Though wider spacing recorded better growth parameters and curd parameters viz., higher dry matter production, curd weight and curd diameter, moderate spacing levels recorded higher plant density compared to wider spacing. These findings are in close accordance with the findings of Bhangre et al., (2011), Saikia et al., (2010), Masood et al., (2003), Fabek et al., (2011), Hossain et al., (2011), Khatun et al., (2011), Solunke et al., (2011) Gogoi et al., (2016) and Vinod et al., (2017) in broccoli

It may concluded that in growth attributes among the cultivars and spacing levels. significantly highest plant height, stalk length $(\mathrm{cm})$, number of leaves per plant, petiole length $(\mathrm{cm})$, leaf area, leaf area index and total dry matter content were recorded in the cultivar Pusa Meghana in $\mathrm{S}_{2}$ spacing level (45 $\mathrm{cm}$ x $45 \mathrm{~cm})$. Pusa Meghana in $\mathrm{S}_{2}(45 \mathrm{~cm} \mathrm{x}$ $45 \mathrm{~cm}$ ) spacing level recorded significantly highest curd weight, curd diameter, CSI and yield per hectare among the cultivars and different plant spacings.

\section{References}

Archana Singh, Avanish Kumar Singh, Raj Shekhar, Rudra Pratap Singh. and DK Singh. 2019. The response of cauliflower var. Snowball affected by different day stages level and spacing distances. Journal of pharmacognosy and phytochemistry.SP3: 04-07.

Arin. L, Salk. A, Deveci, M. and Polat, S. 2003. Investigations on yield and quality of kohlrabi (Brassica oleracea var. gongylodes L.) in the Trakya region of Turkey Trakya. Univ. J. Sci. 4(2): 187-194.

Arora P. N, Jashind B. S, Pandey S. L. 2002. Vegetable crops in India (Book). Indian Hort; 15:19-20.

Atlee C. B, Sciaroni R. H and Heagilivary J. H. 2000. Varietal spacing trials with Brussels sprouts. Veg. Crop. Scr. Univ. Calif. Dvais; 136:11.

Bacha Sah, Mehwish, Shah Sha, Iqbal J, Ahmed A, Shah S. 2017. A review on the production and yield of cauliflower in relation with row spacing and various nitrogen levels. International journal of advanced research and review. 2(8):712.

Bhangre, K. K. Sonawane, P. C and Warade, S. D. 2011. Effect of different varieties and spacing on growth and yield parameters of broccoli (Brassica oleracea var. italica) under Pune conditions, Asian Journal of Horticulture. 6(1):74-76.

EL-Bassiony, A.M, Fawzy, Z. F, EL-Nemr, 
M. A. and Li, Y. (2014). Improvement of growth, yield and quality of two varieties of kohlrabi plants as affected by application of some bio stimulants. $J$. Agric. Res. 3(3):491-498.

Fabek, S., Toth, N., Benko, B. and Peic, I. 2011. The effect of plant density on morphological traits and yield of broccoli. Glasnik Zastite Bilja. 34 (1):22-29.

Gabhale, L.K, Bharad, S.G. and Chaudhari, G.V. (2014 a) Effect of varieties and planting dates on growth and yield of cauliflower. Bioinfolet 11(3A): 806808.

Gogoi, S., Millu, R., Das, P., Bora, N. and Das, B. K. 2016. Effect of sowing dates and spacing on broccoli (Brassica oleracea var. italica) seed production. Indian Journal of Agricultural Research. 50(4):350-353.

Hossain, M. F, Ara, N, Uddin, M.R, Dey, S and Islam, M.R. 2011. Effect of time of sowing and plant spacing on broccoli production. Tropical Agricultural Research and Extension. 14(4): 90-92. Indian Journal of Agricultural sciences. 77(7):448-450.

Joshi, T.N. Budha C.B., Sharma S, Baral S.R. and Pandey N.L. 2018. Effect of different plant spacing on the production of hybrid cauliflower (brassica oleraceae var. Botrytis) under the agro-climatic conditions of mid-hills region Nepal. J plant sci crop protec 1(1): $105 . \quad$ Doi: $10.15744 / 2639$ 3336.1.105

Joshi, T.N. Budha C.B., Sharma S, Baral S.R. and Pandey N.L. 2018. Effect of different plant spacing on the production of hybrid cauliflower (brassica oleraceae var. Botrytis) under the Agro-climatic conditions of midhills region Nepal. Journal of Plant Sciences and Crop Protection1(1): 2639-3336.
Khatiwada P. P. 2000. Plant spacing: A key husbandry practice for rainy season cabbage production. Nepal Agri Res J 4: 48-55.

Khatun, K., Saha, S. R. and Mostrain, T. 2011. Growth and yield of broccoli as influenced by plant spacing. International Journal of sustainable Agricultural Technology. 7(12):7-12.

Masood M, Haidar I and Khan N 2003. Impact of row spacing and fertilizer levels (Diammonium phosphate) on yield and yield components of canola. Asian Journal of Plant Science.2: 4546.

Rahman, A. And M. A. Haque. 1982. Effect of plant density on the growth and yield of cabbage. Bangladesh j. Agric. 7 (34); 9-14.

Saikia Phookan, D.B. and Sanchita Brahma. 2010. Effect of time of planting and planting densities on growth, yield and economic production of broccoli (Brassica oleracea var. italica) cv. Pusa Broccoli KTS-1. Journal of Hill Agriculture. 1(2): 135-139.

Saikia Phookan, D.B. and Sanchita Brahma. 2010. Effect of time of planting and planting densities on growth, yield and economic production of broccoli (Brassica oleracea var. italica) cv. Pusa Broccoli KTS-1. Journal of Hill Agriculture. 1(2): 135-139.

Sharma R. P. and Arora P. N. 1995. Response of mid-season cauliflower to rates and time of nitrogen application and plant density. Indian journal of Agronomy 29: 468-70.

Sorensen and Grevsen. 1994. Effect of plant spacing on uniformity in broccoli for once-over harvest. Gartenbauwissens chaft. 59(5): 102-105.

Srivastava, B. K, Singh, M. P, Singh, P. K. and Singh P. K. (2011). Performance of early cauliflower (Brassica oleracea var. botrytis L) under naturally ventilated 
poly house. Prog. Horti. 43(2): 228230.

Vinod sutar, Aravindakshan, K. and Bola, P.K. 2017. Effect of sowing date and spacing on growth, yield and quality of broccoli (Brassica oleracea var. italica) cultivar. Green head. Chemical science review and letters. 6(21): 209-212.
Zaki, M. F, Saleh, S. A, Tantawy, A. S. and EI-Dewiny, C. Y. (2015). Effect of different rates of potassium fertilizer on the growth, productivity and quality of some broccoli cultivars under new reclaimed soil conditions. Int J. Chem. Tech. Res. 8(12): 28-39.

\section{How to cite this article:}

Ramesha Moratagi, P. Syam Sundar Reddy, Syed Sadarunnisa, V. V. Padmaja and Ramanjaneya Reddy, A. 2021. Effect of Cultivar and Different Plant Spacing on Growth and Yield of Cauliflower under Southern Agro-climatic Zone of Andhra Pradesh. Int.J.Curr.Microbiol.App.Sci. 10(01): 2965-2973. doi: https://doi.org/10.20546/ijcmas.2021.1001.343 